\author{
Leszek Butowski \\ College of Tourism and Recreation in Warsaw \\ University of Vincent Pol in Lublin \\ Institut of Tourism in Warsaw \\ e-mail: leszek.butowski@wp.pl
}

\title{
TOURISM AS A DEVELOPMENT FACTOR IN THE LIGHT OF REGIONAL DEVELOPMENT THEORIES
}

\begin{abstract}
The article concerns theoretical positions on the influence of tourism on regional and local development. The adaptation possibilities of chosen regional development theories for the research needs of the tourism influence on regional development are presented. Four groups were analysed: 1) endogenous development theories; 2) network development theories; 3) economic base theories; 4) polarisation theories. Using works based on these there has been an attempt to indicate the theoretical basis of tourism growth as a factor of regional development.
\end{abstract}

Key words: theories of regional development, tourism as a factor of regional development.

\section{INTRODUCTION}

The aim of the author is to present the main principles of the chosen theories of regional development in the context of their implementation for research on tourism as a development factor in regions. On the basis of the methodological and theoretical analysis of the chosen (historical and contemporary) ideas of regional development, an effort has been made to include an answer to the question of whether tourism can fulfil a developmental function in regions, and if so, which factors are decisive. The theories analysed concern endogenous development, network development, the economic base as well as polarisation. Their selection was not casual. It has been recognised that certain elements of these theories (which can be used together if necessary) can compose the theoretical basis for planning tourism development in regions. The selection proceeded according to the following: 1) theories of endogenous development - a definition of tourism potential; 2) theories of network development - the creation of a tourism product; 3) theories of the economic base - commercialisation of a tourism product. Subsequently theories of polarisation can facilitate spatial planning in the context of the development of tourism reception areas.

\section{THE THEORY OF ENDOGENOUS DEVELOPMENT AND TOURISM RESOURCES IN A REGION}

In adapting endogenous development theory to research on the tourism function in regions, attention should be paid to the value of the area's internal potential as a stimulator of regional (local) development by tourism. The question should then be asked about which internal factors can have an influence on conditions for tourism development. The answer may be looked for in the traditional tourism attractiveness idea consisting of three complex elements: 1) the occurrence and value of tourism assets (attractions); 2) the spatial organisation of tourism; 3) transport accessibility (ROGALEWSKI 1974). In most cases these elements constitute internal (endogenous) factors of the destination area which have an influence on possibilities for tourism development. There is however a quite important weak point in the tourism attractiveness idea which is its narrow character, limited only to tourism. Therefore the list of factors cited above should be extended by other internal elements which have direct and indirect influence on conditions for tourism development in a given area.

In this approach, which assumes the primacy of endogenous factors in regional development, the type and the scope of regional and local authority involvement should be considered as a separate and important issue. In endogenous development theory, the necessity for public intervention is assumed, but 
Tourism 2010, 20/1

$\mathrm{T}$ a b l e 1. Endogenous factors determining regional tourism development

\begin{tabular}{|c|c|c|}
\hline \multirow{5}{*}{$\begin{array}{l}\text { Traditional elements of tourism } \\
\text { attractiveness }\end{array}$} & \multirow[t]{2}{*}{ Tourism assets (attractions) } & $\begin{array}{l}\text { Cultural attractions (man-made): } \\
\text { historical and contemporary }\end{array}$ \\
\hline & & Natural attractions \\
\hline & \multirow{3}{*}{ Spatial tourism arrangement } & Tourism accommodation \\
\hline & & Catering services \\
\hline & & Accompanying services and facilities \\
\hline \multirow{2}{*}{ Territorial marketing elements } & Tourism promotion and information & $\begin{array}{l}\text { Responsibility of public authorities } \\
\text { with private sector participation }\end{array}$ \\
\hline & $\begin{array}{l}\text { Creation and commercialisation of a tourism } \\
\text { product }\end{array}$ & $\begin{array}{l}\text { Responsibility of the private sector } \\
\text { with public institution participation }\end{array}$ \\
\hline \multirow{3}{*}{$\begin{array}{l}\text { Certain elements of technical } \\
\text { infrastructure }\end{array}$} & \multirow{2}{*}{ Transportation infrastructure } & $\begin{array}{l}\text { Assurance of external transportation } \\
\text { accessibility }\end{array}$ \\
\hline & & $\begin{array}{l}\text { Assurance of internal transportation } \\
\text { accessibility }\end{array}$ \\
\hline & \multicolumn{2}{|l|}{ Environmental infrastructure } \\
\hline \multirow{5}{*}{$\begin{array}{l}\text { Social, economic, cultural, political } \\
\text { (institutional infrastructure), } \\
\text { environmental and other } \\
\text { conditionings }\end{array}$} & \multirow[t]{2}{*}{ Local community attitudes towards tourists } & $\begin{array}{l}\text { Friendliness, openness to guests, } \\
\text { knowledge of foreign languages etc. }\end{array}$ \\
\hline & & Entrepreneurship \\
\hline & \multirow{3}{*}{ Public authority activities } & $\begin{array}{l}\text { Economic policy, encouragement } \\
\text { for tourism investments }\end{array}$ \\
\hline & & Assurance of safety \\
\hline & & $\begin{array}{l}\text { Environmental and cultural (historical) } \\
\text { heritage protection }\end{array}$ \\
\hline
\end{tabular}

S o u r c e: Author.

only in the field of development factor stimulation. Now a question may be asked about how this assumption can be adapted to the needs of the tourism regional economy. It seems that the task for regional and local authorities in tourism, according to endogenous development ideas, should be both modern territorial marketing (with aspects of tourism promotion) and the construction of a technical infrastructure (mainly environmental and transportation), which leads to tourism development. Moreover, the specific institutional infrastructure and social environment (friendliness, openness to guests, entrepreneurship, self-organisation) can have important meaning as well.

Endogenous factors affecting tourism development conditions are presented in Table 1. They do not constitute an exclusive list and only the most typical factors (which do not need to appear simultaneously in certain conditions) are presented in this table. The majority form a separate object of research focused on their influence on tourism development. Nevertheless the problem is that the factors cited above have not been analysed in a complex way as a set of reciprocally-related endogenous factors.

In the Polish literature, KACZMAREK, STASIAK \& WŁODARCZYK (2005) postulate the implementation of a comprehensive research approach to tourism potential, but this has been an isolated example. The authors claim that an area's tourism potential is composed of diverse structural resources (tourism assets, the spatial organisation of tourism, transport accessibility and others), as well as functional resources (economic, technological, environmental, political, psychological, socio-demographic and cultural). Such an embrace of tourism potential has already come close to the main principles of endogenous development theory despite the fact that there is no direct reference to this approach.

Summarising the reflections concerning the implementation of endogenous development work on research on regional tourism it could be claimed that it could be successfully applied mainly for the evaluation of a given area's tourism potential. At the same time it is necessary to be aware that this theory does not provide an ideal instrument and it must be extended by others which, for the most part, take into consideration the necessity of contacts with the external world.

\section{THEORIES OF NETWORK DEVELOPMENT IN RESEARCH ON THE TOURISM FUNCTION IN A REGION}

The network development approach contains a group of relatively new theories which try to define vital local, regional and global development factors. It is important to emphasize that there is not only one theory of network development. Different authors pay attention to various kinds of networks, their origin and functions (DZIEMIANOWICZ 2008; GROSSE 2004; JAŁOWIECKI 1999; STRYJAKIEWICZ 1999 \& 2005; SPRENGER 
2001). LISOWSKI (2003) considers that 'network elements are both subjects (entrepreneurs, public authorities) and objects (enterprises, municipalities, cities and economic regions)'. This opinion is close to that of PORTER (2001) who claims that a network is composed of connected enterprises and their 'contractors' operating in related 'branches' as well as the different institutions (academic institutions, chambers of commerce) which collaborate with them. Thanks to spatial proximity they intensify competition in a given area and simultaneously cooperate through necessary horizontal (the same 'branch') and vertical ('interbranch') collaboration as well as by using common resources (GROSSE 2004). In this way a specific network of co-operation and competition is created on a local or regional level. It is important to underline that the theory of network development is closely related to a given area (its economic and socio-cultural conditions). Within this area, specific horizontal and vertical interrelationships happen and 'transactors' (economic and non-economic) choose partners from their regions for co-operation. Thanks to this cooperation, which is conditioned by existing network interrelationships, a given area can gain economic predominance on regional, national or even international markets. It seems that these relationships are the essence of network regional development.

\section{Theory of network development and the tourism} product of an area. The above-cited main principles of network development can be useful in research concerning the tourism function in regions. It is necessary to refer to issues connected to the idea of a tourism product in its grasp of structural and functional components. This idea seems to be crucial in the context of network theory implementation for tourism function research in regions. It emerges from numerous and different components (the heterogeneity of tourism product) which can be classified as elements which create a network both as subjects and objects.

It is worth noticing that in quite a wide variety of work dedicated to tourism product issues, a comprehensive 'network' approach for research into its structural and reciprocal connections is missing in general as well as in a given area (local or regional). Paradoxically, this method has been quite often applied in practice. There are numerous examples of co-operation for putting together different kinds of spatial tourism products. In Poland there are specific organisations Lokalne Organizacje Turystyczne (Local Tourism Organisations) and Lokalne Grupy Działania (Local Activity Groups) which are quite widespread. They were created with a view to encouraging cooperation in tourism product creation on a local resource base. This approach may be found in tourism publicity, tourism training programmes, tourism development strategies as well as in more modest forms in the academic literature. This is of course a positive element, but on the other side it has resulted in considerable terminological disorder as a result of arbitrariness in using the notion network tourism product.

There are several definitions of a tourism network product. According to the Polska Organizacja Turystyczna (Polish Tourism Organisation) definition, a tourism network product is 'a package offer ready for sale which is based on dispersed structure of subjects, attractions, places and service points. This structure acts as a single coherent conception which possesses strength and a strong brand name.' (www. pot.gov.pl). The notion of a tourism network product is quite often used by the Polska Agencja Rozwoju Turystyki (Polish Tourism Development Agency) too (Prezentacja..., 2006). According to this organisation a tourism network product has the following features: 1) a dispersed structure of 'transactors', attractions, places, service points; 2) a common conception and a brand name; 3) an agreement of partners in order to get an additional scale effect in promotional activity as well as in infrastructure, human resources and distribution system development; 4) a high quality of differing marketing solutions; 5) breaking artificial administrative borders; 6) public and private co-operation; 7) the opportunity to use special funds.

In both these definitions, an emphasis has been put on marketing aspects. It is understandable taking into consideration the main goals of these organisations. On the other hand, it should be added that other elements like the spatial aspect, product component diversity and dispersion, as well as their considerable number and reciprocal connections, can be found.

The creation of a new definition of a tourism network product is not the aim of this article. However, the author would like to present some features of one which will decide whether network theory can constitute a useful approach for analysing and researching the influence of spatial tourism products on regional development. For this purpose, a graphic illustration of the spatial tourism product structure in division on a single product (so-called 'eye of a network') and a complete network product (a network structure) was used.

What seems to be especially important in the network approach to a tourism product is its horizontal and vertical structure. The horizontal structure concerns tourism assets (attractions) which should show a certain similarity, necessary for the creation of a tourism product which should be (to a certain extent) quite homogeneous. Simultaneously it allows the value of these tourism attractions in a given area to increase. The horizontal perspective can also concern 
the 'transactors' (within the same branch) who compete with each other but simultaneously need to co-operate. On the other side, the vertical perspective of a tourism product includes tourism assets (attractions) and tourism infrastructure both in objects (tourism services) and subjects (trade partners). In this case, the emphasis is put on the necessity of vertical co-operation among different tourism product components.

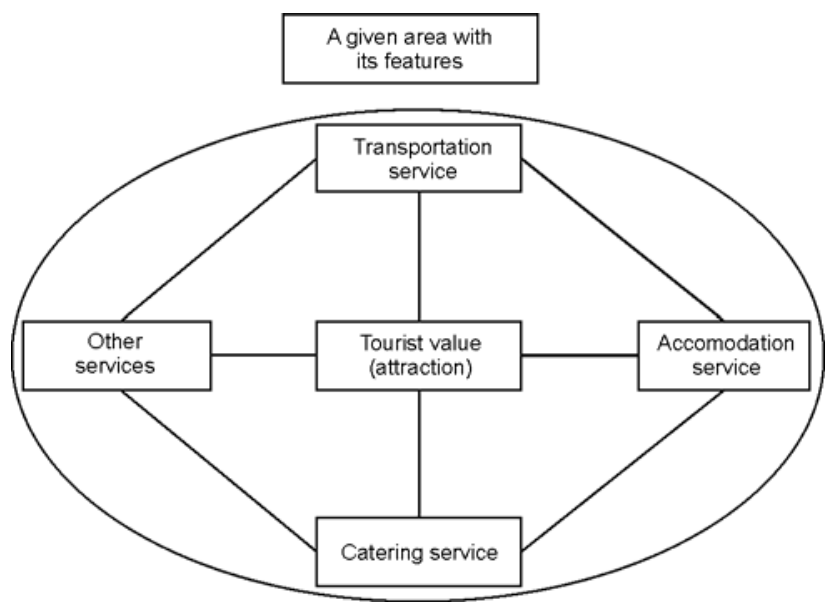

Fig. 1. Single tourism product structure as the 'eye of a network' (s o u r c e: author)

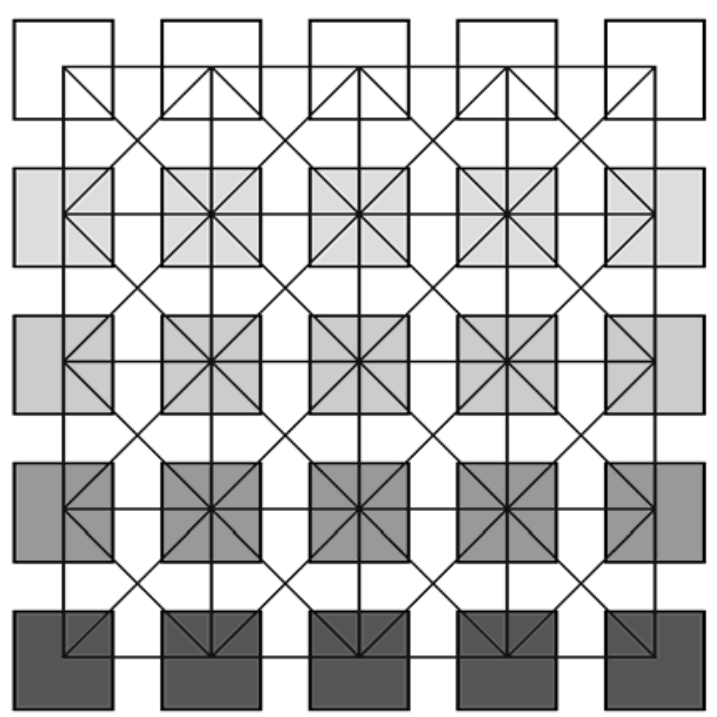

Transportation services

Accommodation services

Tourism assets (attractions)

Catering services

Fig. 2. Tourism network product structure - horizontal and vertical configuration

(s o u r c e: author)
Last but not at least, a tourism product, in a network approach, should be designed relative to the given area without which it could not exist. It means that a network tourism product is a typical spatial product which results in important social, cultural, economic, political, environmental, geographical and other consequences, characteristic for a given area. To a considerable degree, these factors affect the possibility of tourism product creation.

\section{THE THEORY OF ECONOMIC BASE AS A THEORETICAL BASIS OF TOURISM PRODUCT COMMERCIALISATION}

The presented suggestions for implementing the theoretical assumptions behind contemporary regional development ideas should encourage other theories to be analyzed and adapted as well for regional research on tourism. It seems that at least some contain useful research approaches.

Older theories are involved too including economic base theory. Its main principle is to support regional development by export activity, possible thanks to the economic specialisation of a given area (region, country). According to this approach it is the demand for goods and services produced in a given area which decides its economic strength.

Work on the economic base (and similar theories) in research on tourism has been mainly used by geographers and economists. The connections between the economic base theory and tourism functions (from geographical positions) were described among others by FISCHBACH (1989), MATCZAK (1989) and KOWALCZYK (2001). These authors consider that the exogenous function has predominance over the endogenous in a process of tourism area development. However the weak point of the analysis carried out by geographers is that they usually focus on areas with a fullydeveloped tourism function and study the genesis of its creation (a retrospective approach). A wider approach was proposed by BUTOWSKI (1995) when he researched the tourism function as one of numerous activities found in functionally complex, economic and social structures, such as cities.

In turn, relating work on economic base theory to work by economists, its usefulness in research on 'balance of trade' may be indicated, and despite the fact that they rarely directly relate to economic base theory (BLANK 1989), certain analogies can be drawn. They mainly concern the notion of a given area's 'productivity specialisation' which (after fulfilment of certain conditions) can be interpreted as a 'tourism specialisation'. In this context, the tourism specialisa- 
tion of an area can constitute the basis for tourism product export. Considering economic base theory's usefulness for tourism research, the following deserves attention: each tourism product in its essence is intended for export (not only international but on inter-regional or local levels). This phenomenon was noticed by DZIEDZIC (1998) who claims that tourism (on a local scale too) can contribute to the development of a given area through growth of its export possibilities.

However, in research on economic issues in tourism, the problem of tourism services export was mainly perceived as a foreign (international) exchange. Therefore it was of interest in reference to traditional foreign trade. WODEJKO (1998) finds many analogies between tourism service export and foreign trade. According to this author in both cases the exchange is completed with a state credit transfer which should be noticeable in a state's balance of payments. Multiplication effects are to be found in tourism service export as well as in foreign trade. Finally both kinds of exchange can be used for economic growth stimulation, while from the specific nature of the tourism product means that its exchange with foreign countries (or regions) can be treated as an invisible import and export. Since it is one of those balance of payments positions which is connected with service exchange.

On the other hand, in referring to the main assumptions of new trade theory, it is worth mentioning that tourism product export appeared in Polish and foreign literature at the beginning of the 1960s. The first conclusions were quite unilateral though, with authors putting emphasis on positive effects but not considering the negative aspects. It was not noticed that tourism supply is often connected with the necessity for a large-scale import of goods. Such a situation can lead to numerous negative consequences for tourism destination areas, especially where distinct economic disproportions between regions sending and receiving tourists appear (tourism cascade flow theory).

Taking these arguments into consideration, it seems that work based on economic base theory, and new trade theory as well, could be usefully applied in research on the tourism product export consequences for given tourism areas.

\section{THEORIES OF POLARISATION AND TOURISM DESTINATION AREAS}

The essence of polarisation is the assumption that existing imbalance propels development processes which can lead to the appearance of even greater economic development diversity. This approach is thus fundamentally different in relation to neoclassical theories as well as to the group of 'bottom-up' regional development approaches. For these theories assume that achieving a state close to an economic balance, is possible. On the contrary, according to polarisation theories, economic development (from a sectoral and horizontal perspective) in a given area can continue in an unbalanced way.

Looking for an answer to the question about connections between the tourism function in a region and polarisation approaches, CHRISTALLER's (1964) work (among others) should be recalled. This author was well known for publishing his central place theory (in the first half of the $20^{\text {th }}$ c.). Later (in the 1950 's) Christaller presented his so-called peripheral theory concerning functions and in that way constituted the antithesis of central place theory. The author claimed that for tourists the most important factor deciding the choice of tourism destination area was the occurrence of 'natural' resources which are usually situated away from cities. According to this approach, tourists overlook urban centres which do not offer numerous attractions of this kind. Nowadays, the theory of peripheral areas seems somewhat anachronistic, nevertheless it constituted quite an important theoretical basis for the geography of tourism (KOWALCZYK 2001).

Taking into consideration the most important assumptions of different polarisation approaches, and peripheral theory as well, a question about their utility in present research on the tourism function in regions may be asked. The answer seems to be less apparent than in the other theories (endogenous development, network development and economic base). A deeper analysis of polarisation theories gives some ideas enabling two fundamental conclusions to be drawn related to the tourism role in structurally and functionally different areas.

The first conclusion concerns less-developed areas which often possess precious tourism attractions (mainly natural) which constitute the object of interest for tourists from well-developed regions. Referring this situation to the main polarisation theory assumptions, it can be supposed that such differential will be found or even deepened. At the same time, assuming (according to Christaller's peripheral theory) that tourists (mainly from big cities) arrive in these areas, it can be assumed that tourism may constitute one of few development factors existing there. Such conclusions are confirmed by DzIEDZIC (1998). This author, analysing relationships between metropolitan and peripheral areas, notices that tourism can contribute to the economic development of backward regions, including by financial transfers. It seems that such a process occurs in rural areas (including the Polish countryside which is often affected by a long- 
lasting structural crisis), for which development stimulators such as agro-tourism and eco-tourism have been looked for. On a global scale this phenomenon is visible in growth of trips from richer regions (central places) to Third World countries (peripheral areas). On the other hand an open question remains - what real possibilities for development can be offered by implementing a tourism function in peripheral areas, taking into consideration the scale of the crisis there?

The second conclusion concerns the peripheral regions where tourism constitutes one of the most important and existing functions. These are tourism regions and destinations which were formed in different periods in the western part of the Mediterranean as well as numerous tourism regions in the Alps, Greece, Turkey, Canary Islands, Florida, the Bahamas, Hawaii, Mexico, Brazil, Argentina and Indonesia. According to the main assumptions of sectoral polarisation theory, these areas can discount their position while expanding the tourism offer. Simultaneously such activities have innovation hallmarks, considered a necessary condition for keeping and developing chosen areas as 'growth centres'. The theory is also connected with Butler's Tourism Area Life Cycle (TALF) conception (which refers to the diffusion of innovation theory). The author differentiates between the six stages composing TALF. But in the context of the polarisation theories discussed, the most important is the last stage which might lead to the collapse of a given tourism ar ea, but also to its revival (following a stagnation period), as a result of the implemented innovations.

Summarising these reflections it can be concluded that polarisation theory assumptions may be useful for understanding spatial disproportion in tourism locations (which is relatively durable) on a global, national or even regional scale. They explain (to a certain degree) the reasons for the foreground position maintained by chosen areas on the tourism market too. It is worth noting that some conclusions from polarisation and peripheral theory analysis can be useful in certain kinds of activities in practice concerning development programmes in chosen regions. It especially concerns attempts of tourism function implementation in areas which had not fulfilled this role before and placing excessive expectations on it. On the other hand, one should underline that according to polarisation theory, tourism (well-proportioned) may function as an economic development stimulator both in tourism centres and peripheral areas.

\section{BIBLIOGRAPHY}

BLANK U., 1989, The community tourism industry imperative: The Necessity, The Opportunities. Its Potential, State College PA., Venture Publishing, Inc.

BUTLER R.W., 1980, The concept of a tourism area cycle of evolution: implications for management of resources, The Canadian Geographer, 24 (1).

BUTOWSKI L., 1995, Funkcja turystyczna w dużych miastach europejskich. Studium porównawcze Berlina, Budapesztu, Paryża, Pragi, Wiednia i Warszawy, maszynopis WGiSR UW.

BUTOWSKI L., 2007, Turystyka jako czynnik rozwoju regionalnego krytyka metodologii, [in:] Turystyka jako czynnik rozwoju społeczno-gospodarczego regionów europejskich, Europejska Szkoła Hotelarstwa, Turystyki i Przedsiębiorczości. Szkoła Wyższa w Sopocie, pp. 5-13.

BUTOWSKI L., 2009, Turystyka w polityce spójności gospodarczej $i$ społecznej Unii Europejskiej w latach 1994-1999 i 2000-2006. Uwarunkowania teoretyczne, zakres rzeczowy, finansowy i przestrzenny, Wydawnictwo Difin, Warszawa.

CHRISTALLER W., 1964, Some considerations of tourism location in Europe: The peripheral regions - underdeveloped countries - recreation areas, Papers. Regional Science Association, 12, 2, pp. 95-105.

DZIEMIANOWICZ W., 2008, Konkurencyjność gmin w kontekście relacji wtadze lokalne - inwestorzy zagraniczni, Wydawnictwa Uniwersytetu Warszawskiego, Warszawa.

DZIEDZIC E., 1998, Obszar recepcji turystycznej jako przedmiot zarzadzania strategicznego, SGH, Warszawa.

FISCHBACH J., 1989, Funkcja turystyczna jednostek przestrzennych i program jej badania, Acta Universitatis Lodzinsis, Turyzm, no. 5, s. 7-26.

GROSSE T.G., 2004, Polityka regionalna Unii Europejskiej. Przykład Grecji, Włoch, Irlandii i Polski, Instytut Spraw Publicznych, Ośrodek Wydawniczo-Poligraficzny „SIM', Warszawa.

JAŁOWIECKI B., 1999, Metropolie, Wyższa Szkoła Finansów i Zarządzania w Białymstoku, Białystok.

KACZMAREK J., STASIAK, A., WŁODARCZYK B., 2005, Produkt turystyczny, Polskie Wydawnictwo Ekonomiczne, Warszawa.

KOWALCZYK A., 2001, Geografia turyzmu, Wydawnictwo Naukowe PWN, Warszawa.

LISOWSKI A., 2003, Koncepcje przestrzeni w geografii człowieka, Wydział Geografii i Studiów Regionalnych, Uniwersytet Warszawski, Warszawa.

MATCZAK A., 1989, Problem badania funkcji turystycznej miast Polski, Acta Universitatis Lodzinsis. Turyzm, no. 5, pp. 27-39.

Oficjalna strona internetowa Polskiej Organizacji Turystycznej www.pot.gov.pl.

PORTER M.E., 2001, Porter o konkurencji, Polskie Wydawnictwo Ekonomiczne, Warszawa.

Prezentacja Polskiej Agencji Rozwoju Turystyki S.A. pt. „Produkt turystyczny - od pomysłu do projektu współfinansowanego z Europejskiego Funduszu Rozwoju Regionalnego", Gdańsk, 2006.

ROGALEWSKI O., 1974, Zagospodarowanie turystyczne, Wydawnictwa Szkolne i Pedagogiczne.

SPRENGER R.U., 2001, Inter-firm Networks and Regional Networks, National Support Structure ADAPT of the Federal Labour Office, Bonn.

STRYJAKIEWICZ T., 1999, Adaptacja przestrzenna przemystu w Polsce w warunkach transformacji, Wydawnictwo Naukowe Uniwersytetu im. Adama Mickiewicza w Poznaniu, Poznań.

STRYJAKIEWICZ T., 2005, Sieciowa organizacja gospodarki a rozwój regionalny, [w:] Czyż, Rogacki, red., Wspótczesne problemy i koncepcje teoretyczne badań przestrzenno-ekonomicznych, Biuletyn KPZK PAN, z. 219, Warszawa.

WODEJKO S., 1998, Ekonomiczne zagadnienia turystyki, Wyższa Szkoła Handlu i Prawa w Warszawie, Warszawa. 